\title{
Media coverage of climate change in spanish-speaking online media
}

Cobertura sobre el cambio climático en los medios digitales en español

\author{
Carlos Arcila-Calderón / carcila@gmail.com \\ Universidad Rey Juan Carlos, España \\ María Teresa Mercado / mmercado@uchceu.es \\ Universidad CEU Cardenal Herrera, España \\ José Luis Piñuel-Raigada / pinuel@ucm.es \\ Universidad Complutense de Madrid, España \\ Elias Suárez-Sucre / eliasd.suarez@gmail.com \\ Universidad Jorge Tadeo Lozano, Colombia
}

\begin{abstract}
Media attention on climate change (cc) in developing countries is crucial for understanding the discourses that exist in vulnerable zones. Past research has focused on printed media coverage of CC in western developed countries, but there is little knowledge on online media in developing countries. Using framing theory framework, this study analyses the way in which spanish-speaking online media frames news about CC. We carried out a quantitative content analysis of 889 news items from 97 online media outlets that published news about CC during Cop16 (Cancun-2010) and Cop17 (Durban-2011). Findings show that the principal sources are politicians and almost half of the news items came from news wire services. The analysis also indicated an association between the quoted source and the news frame. It is discussed that there exists a 'nationalistic domestication' and that media coverage does not respond to local needs. Further qualitative and comparative analyses are suggested.
\end{abstract}

Key words: climate change, media coverage, Conferences of the Parties, Latin America, spanish-language websites.

Resumen: La atención mediática hacia el cambio climático (CC) en países en desarrollo es crucial para comprender los discursos sobre esta problemática en zonas vulnerables. Las investigaciones previas sobre cobertura mediática al CC se han enfocado en medios impresos de países desarrollados occidentales, pero hay poco conocimiento en medios digitales en países en desarrollo. Usando la teoría del framing, este estudio analiza la manera en que los medios digitales en español enmarcan las noticias sobre cc. Se llevó a cabo un análisis de contenido de 889 noticias de 97 medios que publicaron noticias sobre CC durante las Cumbres de Cancún (2010) y Durban (2011). Los resultados muestran prevalencia de los políticos como fuentes y de agencias noticiosas. También indican una relación entre la fuente y el marco noticioso. Se discute que existe una "domesticación nacionalista" y que no responde a necesidades locales. Se sugieren nuevas investigaciones de corte cualitativo y comparativo.

Palabras clave: cambio climático, cobertura mediática, cumbres del clima, América Latina, medios digitales en español. 


\section{Introduction}

The international scientific consensus on the responsibility of human beings to act on climate change ( $\mathrm{CC}$ ) has meant that the attention of researchers is not solely focused on the issue of global warming itself, but that especial attention is also paid on the socio-cultural aspects of CC, including the practices and discourses that surround this issue. The construction and circulation of discourses in contemporary societies is developed through mass media, which explains the strong interest generated in the last few decades in the study of these forms of communication that transmit content regarding CC.

Media attention on CC in English-language newspapers went from 700 references in the western media in 1988 to 7,500 in 2006. In the United Kingdom, it quadrupled between 2003 and 2006 due to the success of $\mathrm{Al}$ Gore's documentary "An Inconvenient Truth" and the impact of the Stern Report (Boykoff and Roberts, 2007: 6). Schmidt, Ivanova and Schäfer (2013) demonstrate that CC is a relevant issue in 37 media outlets from 27 countries that were included in their study, representing an average of $0.62 \%$ of all news items published between 1997 and 2009. This is compared to media attention for other science-related issues such as stem cell research or human genome, which received less coverage in countries such as Germany, France and the United States over the same period.

This general interest has also been demonstrated in the wide range of scientific literature available on how information related to $\mathrm{CC}$ has been covered. Studies have demonstrated that media attention does not develop in a linear manner, but it fluctuates because of spikes in attention and specific events (Boykoff, 2011). This is particularly the case during the international Conferences of the Parties (COP) for the United Nations Framework Convention on Climate Change (UNFCCC), more commonly known as the United Nations Climate Change Conferences (Brossard, Shanahan and McComas, 2004; Anderson, 2009; Sampei and Aoyagi-Ussui, 2009; Painter, 2010; Liu, Lindquist and Vedlitz, 2011; Schmidt et al., 2013; Kunelius and Eide, 2012).

The majority of the studies have been focused on the media coverage in the United States and Europe. If the studies did include other regions, they were generally limited to english-speaking countries. This is why Anderson (2009: 176) states that future research could explore the reasons for different levels of coverage in different countries, their different emphases and why the views of developing countries are rarely aired. Similarly, it is important to 
consider that there is a need to increase the studies centered on online media given the enormous growth of the news websites and the Internet as a source of news, and the parallel decline of printed news media.

Due to all of these reasons, this study aims to be a starting point for the analysis of online media coverage of CC in Spanish-speaking countries with a specific focus on the annual cop's. Following Kunelius and Eide (2012), "the summits force different kinds of actors and forms of knowledge into a compressed time and space, providing an opportunity for researching climate change politics, social climate, political theory in general and climate journalism in particular" (2012: 268). They understand that COP offers a framework for the trans-national representation of two areas: the politics of CC and climate journalism. For the political actors it is clear that economic interests, technological knowledge, international alliances and the ownership of resources, such as carbon or oil, determine their position in the negotiations.

This study builds on previous studies by Pinuel et al. (2012) and Suárez, Arcila and Pinuel (2013) and describes the way in which online media in Spanish-Speaking countries are presenting news on CC during COP16 in Cancun and Cop17 in Durban, held in December 2010 and December 2011, respectively.

\section{Media coverage of climate change}

The case of CC has especial relevance for social studies. Official reports from international agencies (Pachauri and Reisinger, 2007) state that the consequences of $\mathrm{CC}$ could be mitigated with a change in social behavior, which includes the adoption of socio-economic practices that are environmentally friendly. Therefore, a process to raise social awareness about the issue is necessary. The media have an important role to play in this area.

Boykoff and Roberts (2007: 4) highlight the first references to global warming in printed media in the 1930's. However, it was not until the 1980's when the issue was highlighted in the media. McComas and Shanahan (1999), in their analysis of the media coverage of cc in The New York Times and The Washington Post from 1980 to 1995, identified a peak of interest from these two newspapers in 1988, when the articles had a more pressing and occasionally a desperate tone.

As Ungar (1992) concluded, in order to be part of the media agenda it is necessary for CC to have an impact on the real world: "Environmental 
problems like CC must 'piggyback on dramatic real-world events" (1992: 483). Even if CC was in the media decades before, it was the 1988 heatwave across the United States that awoke interest in the issue. That year also saw the formation of the Intergovernmental Panel on Climate Change (IPCC), established by the United Nations Environment Program (UNEP) and the World Meteorological Organization (WMO). Jaspal and Nerlich (2014: 2) also state that 1988 "can therefore be seen as a crest of a wave of social, political and media recognition of climate change as a global problem in need of global solutions". Cc had transcended the field of science and entered into the socio-political sphere, resulting in an increase in media coverage in the United States (Ungar, 1992; Trumbo, 1996), the United Kingdom (Carvalho and Burguess, 2005) and Germany (Weingart, Engels and Pansegrau, 2000).

The same trend has appeared in other countries. The Project Global Media Map on Climate Change at the University of Hamburg, which measures media attention for CC over a 15-year period in 23 countries from across the World, shows that the coverage of $\mathrm{CC}$ has slowly increased as from 1996, and in particular after 2004 in western countries. Spikes in coverage were noted when the IPCC IV Report was published in 2007 and during the Copenhagen Conference in 2009 (Schmidt et al., 2013).

Cottle (2009: 506) also recognized 2007 as "a transformative moment in the news career of climate change". cc finally came of age as a "global crisis" demanding responses from all the world's nations. Cottle focuses on the use of a visual environmental rhetoric. The western news media's spectacular visualization of CC through dramatic and symbolic scenes collected from around the world has undoubtedly helped to establish its status as a widely recognized global crisis.

The evolution of the number of references to $\mathrm{CC}$ in the mass media can also be demonstrated with a Spanish-language example, that of the El Pais newspaper in Spain. From the first appearance of this term in 1976 until 2009, there were a total 3,547 references over 34 years (Mercado, 2012a: 443-444). In the first ten years of this period there were only 15 mentions of the term "climate change". In 1988 there were four articles that mentioned CC, which highlights an enormous difference in the media coverage of this phenomenon compared to that of the United States due to the different socio-political, economic and journalistic contexts of the two countries. The Earth Summit held in Rio de Janeiro in 1992 resulted in the number of mentions in the El Pais newspaper reaching 62 that year. Up to 1995 there still were a low number of references about CC (96). The negotiations prior to and during COP3 in Kyoto in 1997, generated hundreds of mentions of 
the term CC in El Pais. The reduction of emissions was the main focus of $E l$ Pais until 2007, when CC reached its maximum level of media coverage in the newspaper with 819 mentions.

\section{Climate change in Latin American media}

Media coverage of $\mathrm{CC}$ in regions like Latin America has not been studied extensively or in a cohesive manner. There is little empirical evidence available that examines the behavior of the media in relation to the issue of CC in Latin American Spanish speaking countries and in developed countries such as Spain (Schäfer and Schlichting, 2014). Latin American developing countries are especially vulnerable to the effects of CC. This is why there is a strong interest in the media coverage of $\mathrm{CC}$ in these countries.

In their analysis of CC coverage from 40 newspapers in 17 countries across five continents, Boykoff and Roberts (2007) highlight the clear need for this analysis to be extended to other countries. The only Latin American country analyzed in their study was Honduras. In addition, studies have been undertaken that focused on the region (Fundación Konrad Adenauer, 2008) and on specific countries such as Peru (Takahashi and Meisner, 2013), Argentina (Mercado, 2012b), Mexico (Gordon et al., 2010) or Chile (Dotson et al., 2012). In Mexico, the research analyzed content came from Reforma newspaper, the same media outlet chosen by the previously mentioned Global Media Map on Climate Change Project (Schmidt et al., 2013). Zamith, Pinto and Vilar (2013) have analyzed the framing of cc by the elite press in three South American countries (Argentina, Brazil and Colombia) and the United States in 2009.

Similarly, in the research graphic 2004-2012 World Newspaper Coverage of Climate Change or Global Warming, Boykoff and Mansfield (2012) analyze the media coverage of 50 newspapers in 20 countries from each continent. Given the manner in which samples were taken, the relative trends between the regions are more useful than the figures provided in the study. This warning is clearly necessary in the case of the South America / Africa regions, as only 200 articles were included from the end of 2011 when the Durban conference was held in South Africa. In addition, two of the three newspapers in this category were South African: the third is Clarin, newspaper from Argentina. Focusing therefore on the trends more than the non-comparable figures (10 newspapers from the United Kingdom, 6 from the USA and 5 from Australia); it is in South America and Africa where there was the least amount of increase in media coverage of CC since 2004. 
A peak of interest occurred at the end of 2009 coinciding with cop 15 in Copenhagen, but this peak is lower than in the rest of the regions that were analyzed, above all in Europe, where the conference generated high levels of expectations. In the South America / Africa zones, the highest levels of coverage were at the end of 2010 when Cop 16 was held in Cancun (Mexico), due to a correspondent sent by Clarin newspaper to cover the conference. Highlighted in the chart is the highest peak from this region at the end of 2011 that coincides with COP17 in Durban, a figure that includes media coverage by the two newspapers from the same country which the conference was held in. The proximity of the conference increased media coverage in the zone, a particularly noticeable trend when compared with the noticeable drop in interest from newspapers in Europe and the USA.

\section{Media reporting of COP's and nationalistic domestication}

High-profile international events such as COP are included within the focusing events that intervene as an explanatory variable in the cycles of media attention (Liu, Lindquist and Vedlitz, 2011). Painter (2010) coordinated a study of media coverage of COP 15 in thirteen countries. From 50 newspapers, the study included 5,700 articles related to CC, the highest amount of press coverage since monitoring began in 2004. Also, the Media Climate research project monitored cop's coverage in several countries in two national newspapers (one elite and one popular). After their analysis of the Copenhagen Summit (Eide et al., 2010), they presented a transnational and comparative look at summit coverage in Egypt and South-Africa, Brazil and Indonesia, Bangladesh and Finland (Kunelius and Eide, 2012: 24-25). Their results show varying degrees of dependence on international agencies, "but more importantly, a substantive degree of nationalistic domestication". Journalists tend to address their 'own' politicians, NGO leaders and scientists. Domestication enhances the national interests, uncritically, or points up the lack of action and the superficial nature of their action politics (Kunelius and Eide, 2012: 23).

Dirikx and Gelders (2010:735) selected Dutch and French newspapers to analyze media coverage of Cop's from 2001 to 2007. They explain that a random search of CC articles in Dutch and French newspapers showed that CC was not a prevalent theme in these newspapers, except at critical moments, like international summits. In Spain, León and Erviti (2011: 57) analyze the role of controversy in the current situation of the strong scientific consensus on the existence and origin of cc. They do this through an analysis of the 
coverage of the Copenhagen Summit in the two leading Spanish newspapers (El Pais and El Mundo). This analysis is based on studies such as those of the North American and British press to evaluate the prevalence of "false balance" in the treatment of climate science by the mass media (Boykoff and Boykoff, 2007; Boykoff, 2007).

The results of León and Erviti diverge from other studies in non-U.s. media, in which the portrayal of controversy was very limited (Dispensa and Brulle, 2003; Gordon et al., 2010; Zamith et al., 2013). In the spanish newspapers, controversy is a very relevant element in the presentation of CC and is related to the editorial line of each media. This study confirms that political ideology can work as a filter that overrides scientific knowledge. In principle, the portrayal of controversy is apparently legitimized by an adherence to the journalistic norm of balance. However, balance is only applied when it is useful to present points of view that are linked to the political standpoints of their editorial bias.

With the exception of this study from Spain, there are very few that focus on the coverage of climate summits in developing countries and in the Spanish-speaking media. This gap is the reason why the Hispanic region (linked by culture and language) has been chosen as the focus of this study.

\section{Research questions}

Following Kunelius and Eide (2012) in their attention to how Cop's are mediated across the world, this study is guided by the following research question:

-RQ. How is the coverage of Spanish-language online media to CC during COP's in 2010 and 2011 ?

Thus, we will address the next specific research questions:

-RQ1. Which sources did Spanish-language online media use to cover CC during COP's?

$-\mathrm{RQ} 2$. Are Latin American and Spanish figures included as sources?

-RQ3. Which were the frames used by the media?

$-\mathrm{RQ} 3.1$. What is the position of the discourse in the news items?

$-\mathrm{RQ} 3.2$. What are the solutions proposed by the news items?

$-\mathrm{RQ} 4$. To what extent reports are based on news wire services?

-RQ5. Is there a significant relationship between the source for the news item and the frame of the reporting? 


\section{Theoretical Framework}

This investigation analyses the journalistic coverage of CC from the theoretical perspective of framing, which is understood as the process by which news organizations and journalists feature, emphasize, and/or select certain events, issues, or sources to cover over others (Nisbet, 2009). The framing theory implies that information content not only sets the public agenda, but also implicitly forms a way of thinking about certain issues through news frames.

Entman (1993) explained that frames in the news can be examined and identified by the presence or absence of certain keywords, stock phrases or particular sentences, stereotyped images, and sources. Nisbet (2009) highlights the importance of sources in the news agenda, which are defined as the featured voices, actors or groups in news coverage, such as government officials or environmentalists.

According to Entman (1993: 52) framing is to "select some aspects of a perceived reality and make them more salient in a communicating text, in such a way as to promote a particular problem definition, causal interpretation, moral evaluation, and/or treatment recommendation". In this sense, frames can be understood as the way in which information is presented by: i) the source quoted; $i$ ) the position of the discourse; and, iii) the recommendation, this is to say, the message of its conclusion.

\section{Method}

The goal of this study is examining the treatment given by Spanish-language digital media to the news coverage of CC during the Cancun (2010) and Durban (2012) conferences. To achieve this objective, content analysis was carried out on a sample of news published in Spanish-language media websites, following the established criteria for this quantitative technique (Krippendorff, 2004). Several methods and approaches have been used in CC media coverage research, but a recent overview of the literature in the field has shown that this variety makes "comparison and analysis in one coherent framework much more difficult" (Schäfer and Schlichting, 2014: 145). To address this difficulty and contribute to the vast body of research in the area, this study has chosen the quantitative approach, which is still predominant in the investigation of media coverage of CC (Schäfer and Schlichting, 2014) and of science topics (Schäfer, 2010). 
In relation to the treatment of the content and based on the framing theory, it is possible to focus attention on very different elements, ranging from the selection of sources included in the content to the position of the discourse used to interpret the events covered by the articles. This study has placed attention on both aspects; in the first place, the source (who speaks?) in both their selection and position in the coverage represents an initial element of treatment by the media. On the other hand, the way in which information is framed by the position of the discourse (if the information expresses conformity with the issue or clashes with it) and the message of its conclusion (if it proposes solutions or highlights impasses) also affect how readers perceive this issue. These variables, based on the work by Pinuel et al. (2012), allow for an analysis of the way in which discourses on CC are presented by online media. Analysis of these variables also facilitates an understanding of how online media presents information and how controversy surrounding this issue is communicated to citizens.

\section{Measures}

The following categorical variables were measured with the goal of analyzing the treatment and focus given to the content of the news items relating to CC:

a) Who speaks?; it means the main source of the news item. (1. Afected person /Victim; 2. Witness; 3. Scientific Expert/Technician; 4. Politician; 5. Alleged perpetrator of CC; 6. Activist; 7. Social Organization; 8. Others).

b) Origin of the news item; image and video (1. News wire service; 2. Reporter; 3. Mixed; 4. None).

c) Position of the discourse (1. Expresses conformity; 2. Expresses confrontation; 3. Does not commit to any particular position).

d) Proposal of the conclusion (1. Proposes a solution to the CC as a problem; 2. Impasse (no solution to the problem); 3. Does not propose a problem or solution).

To clarify the key frame categorizations:

C.1. Expresses conformity: News items in which CC and its consequences (political and economic) are framed with conformity. It means that it is assumed as if there was not a problem, one which should be rapidly solved, or as if the current actions were enough to solve it. 
C.2. Expresses confrontation: Unlike the previous category, this includes news items in which either journalists or sources present any inconformity in regard to CC and its consequences.

C.3. Does not commit to any particular position: These news items only make simple informative reports about the summits or CC related topics without any in-depth treatment. There is neither conformity nor confrontation.

D.1 Proposes a solution to the CC as a problem: This frame refers to news items that propose solutions to the problems caused by Cc. For example, it proposes ideas or policies for governments, suggests activities for citizens or presents any solution to avoid the effects of CC.

D.2 Impasse (no solution to the problem): This frame refers to news items that conclude that $\mathrm{CC}$ generated problems but considers that there are no solutions for them.

D.3 Does not propose a problem or solution: This frame does not show any problem or consequence of $\mathrm{CC}$.

\section{Sample}

For the analysis sample, 889 informative pieces were selected using the following parameters:

1. Selection from the most popular online media outlets in 19 Spanish-speaking countries (Argentina, Bolivia, Colombia, Costa Rica, Chile, Dominican Republic, Ecuador, El Salvador, Guatemala, Honduras, Mexico, Nicaragua, Panama, Paraguay, Peru, Puerto Rico, Spain, Uruguay and Venezuela). We consider "popular" following the popularity ranking established by Alexa.com (this ranking is based on commercial web traffic of more than 30 million websites). In total, 97 digital media outlets were selected that: $i)$ provide free access to their news articles, and: $i$ ) had current content indexed in Google News.

2. Through advanced search using Google News, the news articles that had the key words "climate change" and had been published around the dates of the Cop's held in Cancun (29 Nov- 11 Dec 2010) and Durban (29 Nov12 Dec 2011) were selected.

We use "climate change" and not "global warming" because CC is the official name used by the UNFCCC to refer to a change of climate that has been directly or indirectly attributed to human activity. The term 'global warming' was introduced by the scientist Wallace S. Broecker in an article in 
Science magazine in 1975 and is still widespread in the English context, but not in the Spanish-speaking world in which CC is more used. This has been evidenced in previous research (Mercado, 2012b). The texts that mention the term "global warming" always include the term CC as well. For these reasons -official designation, terminological precision and social use in the Spanish language context - and considering that our analysis focuses on what are commonly known as Climate Change Summits, the keywords that were used for the study were "climate change".

In total, 987 news items were archived off-line (in HTML format) before beginning the analysis (March 2012). Later on in the study, a manual verification of each news item was used to confirm the existence of repeated pieces, errors in the dates of publication and if the news items did actually cover the issue of CC. Through this verification process, 107 news items were eliminated from the sample, resulting in the definitive sample of $n=889$ informational pieces.

A comparative study was not carried out because all of the countries selected were heterogeneous and we could not obtain a probabilistic and stratified sample. Our criterion was to cover all Spanish-speaking countries, using a linguistic parameter and the availability of data. In this sense, to focus on the region it was decided that the study would exclude important countries like Brazil (as it is Portuguese-speaking) and include others like Spain (out of the Latin American context, but with many cultural and economic links) to have an overview oh the Hispanic region. However, the main goal of the study was not to make a complete generalization (population inference) (see discussion about generalization in Shapiro, 2002), but to explore the trends and relationships in the selected media (processes inference).

\section{Validity and Reliability}

Two research assistants (coders) who received prior training analyzed the selected news articles. The final coding instrument for the content analysis was submitted to a validity test that relied on the decision of three experts to refine categories for analysis. After this process the reliability of the instrument was evaluated through an intercoder test. Specifically, two independent coders randomly analyzed 100 news items from the sample (more than 10\% of the total news items selected). In the case of the categorical variables, Cohen's kappa coefficient (k) as well as Krippendorff's Alpha (KA) were used, and the values were identical in both indicators: Who speaks? $(\mathrm{k}=0.837 ; \mathrm{KA}=0.837)$, Position of the discourse $(\mathrm{k}=0.963 ; \mathrm{KA}=0.963)$, 
Proposal of the conclusion $(\mathrm{k}=0.876 ; \mathrm{KA}=0.876)$ and Origin of the news item $(k=0.900 ; \mathrm{KA}=0.900)$. All of these variables reached the minimum values expected for $\mathrm{k}$ and $\mathrm{KA}$ ( 0.60 for $\mathrm{k}$ according to Neuendorf, 2002; and 0.70 for KA according to Hayes and Krippendorff, 2007). These tests clearly indicated the reliability of the instrument.

\section{Findings}

Once data were collected, the analysis of the results was carried out using SPSS (Statistical Package for the Social Sciences) software. The central trends of the variables studied were extracted (measures of frequencies, averages and percentages). This was followed by a non-parametric test known as the Chi-squared test of independence $\left(\mathrm{X}^{2}\right)$, with the goal of identifying the existence or not of a statistically significant association between the categorical variables.

It was found that the media coverage of $\mathrm{CC}$ during the Cancun and Durban conferences by news websites demonstrated similar trends (RQ). However, there was an important reduction in the number of news items published in Spanish-language digital media on the issue of cc from 2010 to 2011, dropping from 626 news items to 263.

As indicated in Table 1 , if the total sample $(\mathrm{N}=889)$ is examined, it can be observed that the subjects who are used as sources in articles referring to CC (RQ1) are primarily politicians (36.8\%), followed by witnesses $(20.9 \%)$, experts (14.6\%), and social organizations (11.7\%). These trends were consistent between 2010 and 2011.

Within the news it was found a total of 605 names used as sources and mentioned 1,882 times. Only 34 persons were mentioned more than 10 times and of this group just 4 persons were scientists: Mario Molina, Nobel Prize in Chemistry for his role in elucidating the threat to the Earth's ozone layer of chlorofluorocarbon gases $(n=12)$; Rajandra Pachauri, Chairman of IPCC $(n=13)$; Michel Jarraud $(n=14)$ and Jeremiah Lengoasa, SecretaryGeneral and Deputy Secretary-General of wmo of the World Meteorological Organization (WMO) $(\mathrm{n}=10)$. Additionally, one ecologist was incorporated as a source: Gustavo Ampugnani, Latin American Policy Coordinator at Greenpeace $(n=10)$. UN high-level representatives were also mentioned. Specifically, Christiana Figueres, Executive Secretary of UnfCCC $(n=52)$, and Ban Ki-moon, un Secretary-General of $(n=46)$. 
Mexican President Felipe Calderon $(\mathrm{n}=94)$ was the most mentioned source in our study ( $\mathrm{RQ} 2)$. We can notice that Mexican media had a more complete coverage of COP 16 due to the proximity. Calderon appeared more times than Patricia Espinosa $(n=54)$, who was his Minister of Foreign Affairs. The second most quoted person was Evo Morales $(n=79)$, President of Bolivia, who during Cop16 called for a deal to "save the planet" and sentenced that any agreement must include the "rights of Mother Earth". Thus, the speech of Pablo Solon Romero, Ambassador of Bolivia to the UN and negotiator in Cancun, was covered 32 times by the media. Politicians of other Latin American countries were also significantly quoted in news: Ecuador (President Rafael Correa, $n=38$; María Fernanda Espinosa, $n=29$ ); Venezuela (President Hugo Chavez, $n=35$; Claudia Salerno, $n=12$ ); Brazil (President Luiz Inacio Lula da Silva, $n=26$ ); Argentina (President Cristina Fernandez, n= 23) or Colombia (President Juan Manuel Santos, n=19).

Regarding the frames produced by the position of the discourse (RQ3.1), the findings demonstrated that in general the majority of the information did not commit to a particular position (49.27\%), although an important portion of these news items expressed confrontation (39.37\%) within their content. As it is noticed in Table 2, only a small percentage expressed conformity (11.36\%). Similarly to the previous category, there were no significant differences between the samples from 2010 and 2011.

Although the position of the discourse provides clues about the attributes and focus of the articles, the frames of the proposals of the articles' conclusions were also analyzed (RQ3.2). This category records whether or not a solution was proposed within the article for the problems generated by cc. Table 3 demonstrates that, in general terms, $40 \%$ of the articles did not propose a problem or solution in the news item (a category that reduced considerably from 2010 to 2011), as there was no clear position provided in the general conclusion of the article. However, the study found that almost $40 \%$ of other news items clearly proposed a solution, which means that they included proposals based on improving interactions with the environment and/or within the same social system (Pinuel et al., 2012). This sub-category remained constant between 2010 and 2011. Finally, 19.57\% of the news articles presented an impasse, which means that even though they proposed a problem they did not offer any type of solution. The percentage of articles with impasses increased from 2010 to 2011.

Almost a half (47\%) of the sample of news items studied was from news wire services (RQ4), mainly international agencies such as EFE (36.1\%), AFP (20.49\%), AP (16.34\%), and to a lesser extent regional and national news 
agencies such as Notimex (6.34\%). These wires were published without any editing. In the case of the images, videos and podcasts that were included in the publication of the news item, a large number of these were not attributed to any source (Table 4). Even when AP or AFP has nowadays services in Spanish, EFE (based in Spain) was the first international news wire service exclusively in Spanish with a more complete coverage of Latin American issues, and thus its role in the Spanish-Language media is very relevant.

Politicians were the most quoted sources in the news from wire services $(57.4 \%)$ and in the news written by media reporters (51.3\%). There were not differences in the position presented in the news from wire services and those from reporters: news items that do not commit to any particular position are $47 \%$ in those from wire services and $52 \%$ in those from reporters; news that express confrontation are $39 \%$ in the case of wire services and $38 \%$ in the case of reporters; and news that express conformity are 13\% in wires and $9 \%$ in media reporters' news.

In relation to the proposal of conclusion, in $20 \%$ of the news from wire services and from media reporters there is no solution to the problem (caused by $\mathrm{CC}$ ). Against one could imagine, proposals for solutions are presented in wires to a greater extent (43.2\%), compared to news written by media reporters $(36.3 \%)$. Furthermore, the percentage of news items in which the final paragraphs do not propose a problem or solution was higher in those written by media reporters (43\%) than those from wire services (37.6\%).

With the goal of finding associations between the inclusion of a source and the news frame (position of the discourse and proposal of conclusion) a series of statistical tests $\left(\mathrm{X}^{2}\right)$ were carried out (RQ5).

When victims $\left[\mathrm{X}^{2}(2, \mathrm{~N}=889)=26,383, \mathrm{p}<.01\right](|3.8|>2.58)$ or activists $\left[\mathrm{X}^{2}(2, \mathrm{~N}=889)=19,055, \mathrm{p}<.01\right](|2.6|>2.58)$ appear, there is a trend for the news item to express confrontation. Similarly, when one of the sources is a politician there is a tendency for the article to commit to a particular position $\left[\mathrm{X}^{2}(2, \mathrm{~N}=889)=21,460, \mathrm{p}<.05\right](|-2.2|<-1.96)$, but the analysis does not reveal if it is either conformity or confrontation. Clearly, witnesses were less likely to commit to a particular position $\left[\mathrm{X}^{2}(2\right.$, $\mathrm{N}=889)=28,830, \mathrm{p}<.01](|3.1|>2.58)$ and scientists less likely to express conformity $\left[\mathrm{X}^{2}(2, \mathrm{~N}=889)=8,994, \mathrm{p}<.05\right](|-2.2|<-1.96)$. According to data, the presence of scientists $\left[\mathrm{X}^{2}(2, \mathrm{~N}=889)=36,213, \mathrm{p}<.01\right](|3.4|$ $>2.58)$ and politicians $\left[\mathrm{X}^{2}(2, \mathrm{~N}=889)=14,126, \mathrm{p}<.01\right](|1.9|>1.96)$ is associated with a greater possibility that a solution is proposed in the news item, but when witnesses $\left[\mathrm{X}^{2}(2, \mathrm{~N}=889)=14,126, \mathrm{p}<.01\right](|3.1|>2.58)$, 
activists $\left[\mathrm{X}^{2}(2, \mathrm{~N}=889)=9,188, \mathrm{p}<.05\right](|1.7|>1.96)$ and victims $\left[\mathrm{X}^{2}(2\right.$, $\mathrm{N}=889)=9,144, \mathrm{p}<.05](|2.0|>1.96)$ appear the trend is to not propose a solution.

Additionally, we found that the relationship between the origin of the news item (news wire service, reporter, mixed) and the participation of a politician in the article was significant $\left(\mathrm{X}^{2}(2, \mathrm{~N}=889)=7,840, \mathrm{p}<.05^{*} /\right.$ Fisher's exact $=0.019<0.05)$, but it was not possible to find which factor within the variables strengthened the relationship. It was also found that when a witness was the source there was a lower tendency that the origin of the article was mixed $\left(\mathrm{X}^{2}(2, \mathrm{~N}=889)=12,644, \mathrm{p}<.01 /\right.$ Fisher's exact $=0.001$ $<0.01)(|-2.1|<-1.96)$. The data analysis did not show any association between the origin of the news item and the position of the discourse or the proposal of conclusion.

\section{Discussion}

The significant decline (by 65\%) in the number of news items between 2010 and 2011 is consistent with the findings of Boykoff and Mansfield (2012) in their analysis of the European media: almost 600 news items referred to Cop 16 in Cancun while just over 400 covered cop 17 in Durban. This trend did not occur in the media in the United States, where coverage slightly increased over the same period. This can be linked to the dependence of the news websites included in this study on the international news agencies based in Europe (near $70 \%$ of the total) where the worsening of the economic situation in 2011 increased interest in economic or work-related news, to the detriment of other issues such as CC. Moreover, as our data revealed, the news items with frames of no solution proposed (impasses) increased from 2010 to 2011, which we infer may also be related to the change of the economic context in those years.

Likewise, the context in which media content is created and transmitted is of especial importance. In the case of news items on CC that were broadcast by television networks in Spain during the Cancun and Durban conferences, Gaitan and Pinuel (2013) demonstrated a relationship between the economic crisis and the discourse on CC presented to audiences. Building on this research, the data is confirmed by Aguila (2013) in a study that shows how the coverage of these events by television networks dropped between COP in Cancun and following year's meeting in Durban, precisely because the economic crisis the country faced in the same period increased. This 
demonstrates how the constrictions of the economic system noticeably affect the development of discourses and content with topics of general interest.

In Latin America there is an even more marked decline between the coverage of the two conferences as that the first (COp 16) was held in Mexico. The large Latin American media organizations covered this international conference, sending special correspondents that filed daily reports on the negotiations. These were discussions that involved important leaders from these countries and the declarations from the Conference had a resounding impact on media coverage from the region. As it has been previously observed in relation to the coverage of COp's, politicians are the actors who are most quoted as they are the main participants in the negotiations, much more so than experts or scientists.

Similar studies in countries across the region that were not specifically focused on an analysis of cop's also concluded that politicians were the most quoted sources in the media coverage of CC. In a study of 1,628 articles on CC published in 2003, 2005 and 2007 in Chile (Dotson et al., 2012), the politicians represented $57 \%$ of the sources quoted in the El Mercurio and $68 \%$ in La Nación, while experts were quoted in $22 \%$ and $21 \%$ of the articles on CC, respectively.

Supporting the contributions of Liu, Lindquist and Vedlitz (2011: 407), Schmidt et al. (2013) affirm that the coverage of these conferences is part of the media relations approach to CC, describing what is at stake in terms of the consequences of $\mathrm{CC}$ and utilizing the high profile of political actors who participate in these international negotiations. During the summits, the politics of $\mathrm{CC}$ are reduced to being a purely international component (Brossard et al., 2004).

In the initial reports on global warming when the issue first appeared in the public agenda, scientists were the main sources of information, but later on politicians and interest groups (industry and environmental) came into picture (Trumbo, 1996). Wilkins (1993) highlights that in 1990, the majority of sources cited in news items on global warming shifted from scientists to politicians and interest groups. The change from a discussion dominated by science to a discussion led by political and industry figures might have contributed to the confusion surrounding CC that exists in the United States media (Williams, 2001).

Painter (2010) confirms that in the media coverage of COP15 in Copenhagen scientists were hardly quoted, with the scientific perspective being secondary to politicians and industry leaders. In the 427 articles 
analyzed, almost $80 \%$ of the news items had less than $10 \%$ of their content specifically relating to CC science. Only $9 \%$ of the texts dedicated more than a half of their content to scientific aspects with 22 of these 34 articles published in western media outlets (Australia, Italy, UK, USA) that directly quoted scientific organizations like IPCC and NGOs. Kunelius and Eide also highlight the limited presence of politicians in Copenhagen, despite the unprecedented number of scientists who were present and the abundance of scientific information that was available. "This implies that scientists were not actively included (by journalism) in the political bargaining" (2012: 275). "Official sources are more likely to present mainstream and status-quo views and partake in conflict scripts among institutional actors, limiting thus the scope of possible concerns and solutions presented in the press" (Zamith et al., 2013: 350).

Addressing RQ1, in the Spanish-speaking Online Media our data confirm that politicians are the main sources of news. Only 4 scientists declare (previously mentioned: Mario Molina, Rajandra Pachauri, Michel Jarraud and Jeremiah Lengoasa). Molina in COP 16, as he is Mexican, and the others because WMO presented in COP17 its Climate Annual Report, which stated that thirteen of the warmest years recorded have occurred within the last decade and a half. Very significant was the appearance of just one ecologist. Our study also found that witnesses were important sources $(20.9 \%)$ during the coverage of cop's, even more quoted than scientists (14.6\%).

Furthermore, the media treatment of COP16 indicates a nationalistic domestication (Kunelius and Eide, 2012) by Latin American media at two levels (RQ2). In one level the domestication refers to Mexico as the COp16 host country: there is a high percentage of Mexican politicians used as sources in the news analyzed in this study. Besides Mexican president and the Mexican organizer of COP16, there were important quotes by Marcelo Ebrard Casaubón, head of the Government of Federal District. The most quoted scientist (M. Molina) is also Mexican. Hence, in Cancun, the large presence of Mexican politicians seems to present the nation as a global actor.

At another level, we can observe this domestication as a region. The Presidents of Bolivia, Ecuador, Venezuela and Brazil (as well as the Ecuadorian Minister of Foreign Affairs) were more quoted than international names such as Barak Obama, Connie Hedegaard (European Commissioner for Climate Action) and Todd Stern (United States Special Envoy for Climate Change). In Cop 16 in Cancun, the media preferred to include high political leaders (as presidents) instead of technical actors, like Juan Elvira Quesada, Mexican Secretary of Environmental Issues. Nonetheless, in cop 17 
in Durban, Maite Nkoana-Mashabane, President of cop and Secretary of International Relations and Cooperation of South Africa, was even more quoted than President Jacob Zuma.

RQ3.1 and RQ3.3 address CC news frames. These frames were divided into those that did not commit to any particular position (news items concerning major declarations on the issue) and others in which the journalist included confrontation and highlighted the opposition to the policy or actions that are the subject of the article.

Almost a half of the sample of the news items studied came from international news wire services ( $R Q 4)$, coinciding with the results from the research by Takahashi and Meisner (2013), which examines the role of news agencies in media treatment of CC in Peru. This eliminates the capacity of online media to consult local actors. Liu et al. (2011) emphasize the importance of local and regional commitments made by media organizations regarding CC. Therefore the inclusion of a high percentage of news items from international agencies shows the lack of a connection between the global problem and concerns and action at a local level. However, our data shows no significant differences of treatment in items from news agencies and those written by media reporters. In both cases politicians (and their agendas) are extremely relevant, instead of agents of recognition such as ecologists and experts. Our findings suggest that Spanish-Speaking Online Media do not take advantage of COP's to bring CC topics to media readers closer.

$\mathrm{RQ} 5$ suggested that some actors of CC (victims or activists) are more likely to have a confrontational position that may be understood as a position of protest with current policies. This trend is confirmed when we observed that scientists (the first to alert about CC causes and consequences) were less likely to express conformity. This way, there is a relationship between the speaker and the way their speech is presented in the news item.

This last finding has theoretical and practical implications. In the first place, it is clear that our results confirm framing theoretical framework and suggest it is a useful approach to understand media coverage. The incorporation or not of a source changes the way news items are presented in media, thus the framing process begins when the journalist has to choose who speaks about CC. On the other hand, this fact might orientate specialized journalistic practice. Those who give the information significantly affect news writing, so if journalists are aware of this effect, the final news frame can be less sensitive to the source. This can also change the influence of public understanding and political decision-making in society (Hansen, 2011). 


\section{Conclusions $^{1}$}

The data included in this study can be used to improve the understanding of how CC is covered by online media in Spanish-speaking countries. We found that the media treatment focuses on the political debate and there is a significant association between quoted sources and the news frame. Data also showed that a significant body of news came from news wire agencies and that sources were especially related to countries' media, which implies a nationalistic domestication. Thus, our study reveals that foreign coverage trends are similar in the Hispanic region, and this empirical evidence aims to reduce the gap in CC media coverage research in non English-speaking countries and developing nations. Moreover, the link between the quoted source and CC news frames supports the framing theoretical approach, which serves as an adequate framework for news coverage analysis.

This study hasits limitationsin terms of samplesize and representativeness, and is an initial approximation for research on cC in Latin America and Spain. This research area can continue to be advanced, above all by incorporating an analysis of qualitative discourses in the search for a more in-depth approach to the problems surrounding $\mathrm{CC}$ in the media, as an instrument to raise social awareness and the first step towards taking action. Future research may also incorporate a comparative analysis to detect any significant difference in the way each country of the region covers CC.

\section{Bibliography}

Anderson, Alison (2009), "Media, Politics and Climate Change: towards a new research agenda”, in Sociology Compass, vol. 3, no. 2, Maiden (MA), USA.

Águila, Juan (2013), "El framing en las noticias sobre las cumbres del cambio climático en la televisión española", in Anuario Electrónico de Estudios de Comunicación Social "Disertaciones", vol. 6, no. 1, San Cristóbal, Venezuela.

Boykoff, Maxwell and Boykoff, Jules (2007), "Climate change and journalistic norms: A case-study of us massmedia coverage”, in Geoforum, vol. 38, no. 6, Philadelphia (PA), USA.

Boykoff, Maxwell (2011), Who Speaks for Climate, Cambridge: Cambridge University Press.

1 The authors would like to thank the Spanish Ministry of Science and Innovation for the economic support given to R\&D Project Ref. cso2010-16936 directed by J. L. Pinuel. The authors would like to recognize the support they received from Observatorio de Medios $y$ Opinión Pública of Universidad del Norte (Colombia) and Università degli Studi di Napoli "Federico II" (Italy) to undertake this study. 
Boykoff, Maxwell (2007), "Flogging a dead norm? Newspaper coverage of anthropogenic climate change in the United States and United Kingdom from 2003 to 2006", in Area, vol. 39, no. 4, Maiden (MA), USA.

Brossard, Dominique, Shanahan, James and McComas, Katherine (2004), "Are issue-cycles culturally constructed? A comparison of French and American coverage of global climate change", in Mass Communication and Society, vol. 7, no. 3, Reino Unido.

Carvalho, Anabela and Burgess, Jacquelin (2005), "Cultural Circuits of Climate Change in U.K. Broadsheet Newspapers, 1985-2003", in Risk Analysis, vol. 25, no. 6, Maiden (MA), USA.

Cottle, Simon (2009), "Global Crises in the News: Staging New Wars, Disasters, and Climate Change”, in International Journal of Communication, no. 3, Los Angeles, USA.

Dirikx, Astrid and Gelders, Dave (2010), “To frame is to explain: a deductive frame-analysis of Dutch and French climate change coverage during the annual UN Conferences of the Parties", in Public Understanding of Science, vol. 19, no. 6, UsA.

Dispensa, Jaclyn and Brulle, Robert (2003), "Media's social construction of environmental issues: focus on global warming - a comparative study", in International Journal of Sociology and Social Policy, vol. 23, no. 10, Bingley, United Kingdom.

Dotson, Devin et al. (2012), "Media coverage of climate change in Chile: A content analysis of conservative and liberal newspapers", in Environmental Communication: A Journal of Nature and Culture, vol. 6, no. 1, United Kingdom.

Eide, Elisabeth, Kunelius, Risto and Kumpu, Ville (eds.) (2010), Global climate - local journalisms: A Transnational Study of how Media make Sense of Climate Summits, Bochum: Projektverlag.

Entman, Robert (1993), “Framing: toward clarification of a fractured paradigm”, in

Journal of Communication, vol. 43, no. 3, Maiden (MA), USA.

Gaitán, Juan and Pinuel, José (2013), "Efectos de la crisis en el discurso sobre el Cambio Climático desde Cancún a Durban”, in Anuario Electrónico de Estudios de Comunicación Social "Disertaciones", vol. 6, no. 1, San Cristóbal, Venezuela.

Gordon, Joye, Deines, Tina and Havice, Jacqueline (2010), "Global Warming Coverage in the Media: Trends in a Mexico City Newspaper”, in Science Communication, vol. 32, no. 2, USA.

Hayes, Andrew and Krippendorff, Klaus (2007), "Answering the Call for a Standard Reliability Measure for Coding Data", in Communication Methods and Measures, vol. 1, no. 1, United Kingdom.

Hansen, A. (2011), “Communication, media and environment: Towards reconnecting research on the production, content and social implications of environmental communication", in The International Communication Gazette, vol. 73, no. 1-2, USA.

Jaspal, Rusi and Nerlich, Brigitte (2014), "When climate change became climate politics: British media representations of climate change in 1988", in Public Understanding of Science, vol. 23, no. 2, USA.

Krippendorff, Klaus (2004), Content Analysis. Thousand Oaks, CA: Sage. 
Kunelius, Risto and Eide, Elisabeth (2012), "Moment of hope, mode of realism: On the dynamics of a transnational journalistic field during UN climate change summits", in International Journal of Communication, no. 6, Los Angeles, USA.

León, Bienvenido and Erviti, María (2011), "Portrayal of scientific controversy on climate change. A study of the coverage of the Copenhagen summit in the Spanish press", in Observatorio ( ${ }^{*} \mathrm{OBS}$ ) Journal, vol. 5, no. 3, Portugal.

Liu, Xinsheng, Lindquist, Eric and Vedlitz, Arnold (2011), "Explaining Media and Congressional Attention to Global Climate Change, 1969-2005: An Empirical Test of Agenda-Setting Theory", in Political Research Quarterly, vol. 64, no. 2, UsA.

McComas, Katherine and Shanahan, James (1999), in "Telling stories about global climate change", Communication Research, vol. 26, no. 1, UsA.

Mercado, María Teresa (2012a), "Periodismo ambiental: entre la especialización y el compromiso", in Fernández Sanz and Rubio Moraga (eds.), Prensa y periodismo especializado $V$., Proceedings of Congreso Prensa y Periodismo Especializado.

Mercado, María Teresa (2012b), "Media representation of climate change in the Argentinean Press”, in Journalism Studies, vol. 13, no. 2, United Kingdom.

Neuendorf, Kimberly (2002), The Content Analysis Guidebook, Thousan Oaks, CA: Sage.

Nisbet, Matthew (2009), "Communicating Climate Change: Why Frames Matter for Public Engagement”, in Environment: Science and Policy for Sustainable Development, vol. 51, no. 2, United Kingdom.

Pachauri, Rajendra and Reisinger, Andy (eds.) (2007), Climate Change 2007: Synthesis Report, Geneva: Intergovernmental Panel on Climate Change (IPCC).

Pinuel, José et al. (2012), Comunicación, controversias e incertidumbres frente al consenso cientifico acerca del Cambio Climático, Tenerife: Sociedad Latina de Comunicación Social.

Sampei, Yuki and Aoyagi-Usui, Midori (2009), "Mass-media coverage, its influence on public awareness of climate-change issues, and implications for Japans national campaign to reduce greenhouse gas emissions", in Global Environmental Change, vol. 19, no. 2, Philadelphia, UsA.

Schmidt, Andreas, Ivanova, Ana and Schäfer, Mike (2013), "Media Attention for climate change around the world: A comparative analysis of newspaper coverage in 27 countries", in Global Environmental Change, vol. 23, no. 5, Philadelphia, USA.

Schäfer, M. and Schlichting, I. (2014), "Media Representations of Climate Change: A Meta-Analysis of the Research Field”, in Environmental Communication, vol. 8, no. 2, United Kingdom.

Shapiro, Michael (2002), "Generalizability in Communication Research", in Human Communication Research, no. 28, UsA.

Suárez, Elias, Arcila, Carlos and Pinuel, José (2013), “Tratamiento de la temática referente al cambio climático en los medios digitales españoles”, in Anuario Electrónico de Estudios de Comunicación Social "Disertaciones”, vol. 6, no. 1, San Cristóbal, Venezuela.

Takahashi, Bruno and Meisner, Mark (2013), "Climate change in Peruvian newspapers: The role of foreign voices in a context of vulnerability", in Public Understanding of Science, vol. 22 , no. 4 , USA. 
Trumbo, Craig (1996), "Constructing climate change: Claims and frames in U.s. news coverage of an environmental issue", in Public Understanding of Science, vol. 5, no. 3, USA.

Ungar, Sheldon (1992), “The rise and (relative) decline of global warming as a social problem”, in Sociological Quaterly, vol. 33, no. 4, Malden (MA), USA.

Wilkins, Lee (1993), "Between facts and values: Print media coverage of the greenhouse effect, 1987-1990", in Public Understanding of Science, vol. 2, no. 1, UsA.

Weingart, Peter, Engels, Anita and Pansegrau, Petra (2000), "Risk of communication: Discourses on climate change in science, politics, and the mass media", in Public Understanding of Science, vol. 9, no. 3, UsA.

Williams, Jerry (2001), The rise and decline of public interest in global warming: toward a pragmatic conception of environmental problems, Huntington, NY: Nova Science.

Zamith, Rodrigo, Pinto, Juliet and Vilar, María (2013), "Constructing Climate Change in the Americas: An Analysis of News Coverage in U.s. and South American Newspapers", in Science Communication, vol. 35, no. 3, USA.

\section{Electronic references}

Boykoff, Maxwell and Roberts, Timmons (2007), Media coverage of climate change: current trends, strengths, weaknesses [United Nations Report]. Retrieved from: http://hdr. undp.org/en/reports/global/hdr2007-2008/papers/Boykoff,\%20Maxwell\%20 and\%20Roberts,\%20J.\%20Timmons.pdf (March 11 $\left.{ }^{\text {th }}, 2009\right)$.

Boykoff, Maxwell and Mansfield, Maria (2012), World Newspaper Coverage of Climate Change/Global Warming. Retrieved from: http://sciencepolicy.colorado.edu/media_ coverage/index.html (July $\left.1^{\text {st }}, 2013\right)$.

Fundación Konrad Adenauer (2008), El tratamiento del cambio climático en la prensa latinoamericana [Report]. Retrieved from http://www.kas.de/wf/doc/kas_133921522-4-30.pdf?110224152514 (March 11 $\left.{ }^{\text {th }}, 2009\right)$. http://www.oem.com.mx/oem/ notas/n1878203.htm (June 15 $\left.5^{\text {th }}, 2012\right)$.

Painter, James (2010), Summoned by Science. Reporting Climate Change at Copenhagen and Beyond. Reuters Institute for the Study of Journalism [Report]. Retrieved from: https:// reutersinstitute.politics.ox.ac.uk/fileadmin/documents/Publications/Challenges/ Summoned_by_Science.pdf (March 30 $\left.{ }^{\text {th }}, 2011\right)$. 


\section{Appendix}

\section{Table 1}

\section{Who speaks?}

\begin{tabular}{lrrrrrr}
\hline & \multicolumn{2}{c}{ Responses 2010 } & \multicolumn{2}{c}{ Responses 2011 } & \multicolumn{2}{c}{$\begin{array}{c}\text { Total number of } \\
\text { Responses }\end{array}$} \\
\cline { 2 - 8 } & No. & $\%$ & No. & $\%$ & No. & $\%$ \\
\hline Activists & 51 & 5.59 & 32 & 7.70 & 83 & 6.30 \\
\hline Those affected/Victims & 37 & 4.07 & 13 & 3.16 & 50 & 3.80 \\
\hline Social Entities & 104 & 11.45 & 50 & 12.06 & 155 & 11.70 \\
\hline $\begin{array}{l}\text { Experts/Scientists/ } \\
\text { Technicians }\end{array}$ & 133 & 14.62 & 60 & 14.46 & 194 & 14.60 \\
\hline Those responsible & 12 & 1.31 & 4 & 0.95 & 16 & 1.20 \\
\hline Others & 49 & 5.38 & 14 & 3.35 & 63 & 4.80 \\
\hline Concerned Politicians & 362 & 39.86 & 126 & 30.37 & 488 & 36.80 \\
\hline Witnesses & 161 & 17.72 & 116 & 27.97 & 277 & 20.90 \\
\hline Total & 909 & 100.00 & 415 & 100.00 & 1326 & 100.10 \\
\hline Source: & & & & & & \\
\hline
\end{tabular}

Source: own elaboration.

Table 2

\section{Position of the news item}

\begin{tabular}{lrcrccc}
\hline & \multicolumn{2}{c}{2010} & \multicolumn{2}{c}{2011} & \multicolumn{2}{c}{ Total } \\
\cline { 2 - 7 } & No. & $\%$ & No. & $\%$ & No. & $\%$ \\
\hline Expresses Conformity & 77 & 12.30 & 24 & 9.13 & 101 & 11.36 \\
\hline $\begin{array}{l}\text { Expresses } \\
\text { Confrontation }\end{array}$ & 246 & 39.30 & 104 & 39.54 & 350 & 39.37 \\
\hline $\begin{array}{l}\text { Does not commit to } \\
\text { any particular position }\end{array}$ & 303 & 48.40 & 135 & 51.33 & 438 & 49.27 \\
\hline Total & 626 & 100.00 & 263 & 100.00 & 889 & 100.00 \\
\hline
\end{tabular}

Source: own elaboration. 


\section{Table 3}

Proposal of conclusion included in the news item

\begin{tabular}{lcccccc}
\hline & \multicolumn{2}{c}{2010} & \multicolumn{2}{c}{2011} & \multicolumn{2}{c}{ Total } \\
\cline { 2 - 7 } & No. & $\%$ & No. & $\%$ & No. & $\%$ \\
\hline Impasse (no solution) & 107 & 17.09 & 67 & 25.48 & 174 & 19.57 \\
\hline Solution is proposed & 246 & 39.30 & 109 & 41.44 & 355 & 39.93 \\
\hline $\begin{array}{l}\text { No problem is included } \\
\text { in the news item }\end{array}$ & 273 & 43.61 & 87 & 33.08 & 360 & 40.49 \\
\hline Total & 626 & 100.00 & 263 & 100.00 & 889 & 100.00 \\
\hline
\end{tabular}

Source: own elaboration.

Table 4

Origin of news, images and videos

\begin{tabular}{|c|c|c|c|c|c|c|c|c|}
\hline & \multicolumn{2}{|c|}{$\begin{array}{c}\text { Source of the } \\
\text { news item }\end{array}$} & \multicolumn{2}{|c|}{$\begin{array}{c}\text { Source of the } \\
\text { image }\end{array}$} & \multicolumn{2}{|c|}{ Source of videos } & \multicolumn{2}{|c|}{$\begin{array}{l}\text { Source of } \\
\text { podcasts }\end{array}$} \\
\hline & No. & $\%$ & No. & $\%$ & No. & $\%$ & No. & $\%$ \\
\hline $\begin{array}{l}\text { News wire } \\
\text { services }\end{array}$ & 417 & 47.0 & 247 & 27.9 & 3 & 0.3 & 3 & 0.3 \\
\hline Reporter & 446 & 50.1 & 232 & 26.1 & 7 & 0.8 & 9 & 0.8 \\
\hline Mixed & 25 & 2.8 & 9 & 1.0 & 0 & 0 & 0 & 0 \\
\hline None & 0 & 0 & 400 & 44.9 & 878 & 98.8 & 876 & 98.8 \\
\hline Total & 889 & 100.0 & 889 & 100.0 & 889 & 100.0 & 889 & 100.0 \\
\hline
\end{tabular}

Source: own elaboration.

Carlos Arcila Calderón. University Rey Juan Carlos (Spain), PhD in Communications. Research field: Digital communication and Journalism. Recent publications: C. Arcila, M. Calderín \& C. Castro (eds.), An Overview to Digital Media in Latin America, London: University of West London (2014); C. Arcila, J. Piñuel and M. Calderín, "e-Investigación en Comunicación: Actitudes, herramientas y prácticas en los investigadores iberoamericanos", in Comunicar: Revista Cientifica de Comunicación y Educación, 40 (2013); C. Arcila and E. Said, "Factores que inciden en la variación de seguidores en los usuarios TOP20 más vistos en Twitter en América Latina y Medio Oriente", en Interciencia, vol. 37, no. 12 (2012). 
María Teresa Mercado. University Ceu Cardenal Herrera (Spain), PhD in Communications. Research field: Environmental communication. Recent publications: M. T. Mercado, A. Álvarez \& J. Herranz, "Le fracking au coeur du débat dans les médias: le rôle des plateformes citoyennes comme source d'information", in ESSACHESS-Journal for Communication Studies, no. 13 (2014); S. Sánchez Castillo and M. T. Mercado, "El encuadre de las enfermedades raras en la prensa española", in Anuario Electrónico de Estudios en Comunicación Social "Disertaciones", vol. 7, no. 1 (2014); M. T. Mercado, "Media representations of climate change in the Argentinean press", in Journalism Studies, vol. 13, no. 2 (2012).

José Luis Piñuel Raigada. Universidad Complutense de Madrid (Spain), $\mathrm{PhD}$ in Philosophy and Social Psychology. Research field: Communication methods and theories. Recent publications: J. L. Piñuel, J. A. Gaitán and C. Lozano, Confiar en la prensa o no. Un método para el estudio de la construcción mediática de la realidad, Salamanca: Comunicación Social, Colección Metodologías Iberoamericanas de la Comunicación (2013); C. Arcila, J. Piñuel and M. Calderín, "e-Investigación en Comunicación: Actitudes, herramientas y prácticas en los investigadores iberoamericanos", in Comunicar: Revista Cientifica de Comunicación y Educación, vol. 40 (2013); J. L. Piñuel and J. A. Gaitán, "El discurso hegemónico sobre la verdad y la comunicación en la autorreferencia mediática en Prensa”, in Revista Latina de Comunicación Social, vol. 13, no. 65 (2010).

Elias Suárez Sucre. Sergio Arboleda University (Colombia), Master in Communications. Research field: Digital communication and Journalism. Recent publications: E. Suárez, C. Arcila Calderón and J. Piñuel Raigada, "Tratamiento de la temática referente al cambio climático en los medios digitales españoles. Estudio enmarcado en las cumbres del cambio climático de Cancún (2010) y Durban (2011)", in Anuario Electrónico de Estudios en Comunicación Social "Disertaciones", vol. 6, no. 1 (2013).

Recepción: 5 de septiembre de 2014.

Aprobación: 10 de febrero de 2015. 
